\title{
GAMBARAN KELUHAN MUSKULOSKELETAL DAN KELELAHAN SEBELUM DAN SETELAH BEKERJA PADA PEKERJA DI UD. BATU BUKIT
}

\author{
Utomo Wicaksono*1, Luh Made Indah Sri Handari Adiputra ${ }^{2}$ \\ ${ }^{1}$ Mahasiswa Program Studi Magister Ergonomi Fisiologi Kerja Universitas Udayana \\ ${ }^{2}$ Dosen Program Studi Magister Ergonomi Fisiologi Kerja Universitas Udayana \\ e-mail: tomwicaksono@gmail.com
}

\begin{abstract}
Workers at UD. Batu Bukit in carrying out its work activities is exposed to non-ergonomic working conditions. This condition cannot be separated from the risk factors that can lead to problems in the form of musculoskeletal complaints and fatigue. The purpose of this study was to determine the musculoskeletal complaints and fatigue experienced by workers before and after work. This study was used an evaluative research design with a sample of 11 people. Data were obtained by interview and using a Nordic Body Map questionnaire to measure musculoskeletal complaints before and after work and a 30 Items of Rating Scale questionnaire to measure fatigue before and after work. The data before and after working on the variables were statistically analyzed with SPSS version 26.0. The results of data analysis showed an increase in musculoskeletal complaints before and after work significantly $(p=0.00 ; C I=35.94-41.70)$ by $122.66 \%$, and an increase in fatigue before and after work significantly $(p=0.00 ; C I=45.34-49.39)$ of 132.22\%. Working conditions at UD. Batu Bukit requires corrective action to improve occupational health by considering the capabilities of small industries.
\end{abstract}

Keywords: fatigue, musculoskeletal disorders, occupational health, small industries

\begin{abstract}
Abstrak
Pekerja di UD. Batu Bukit dalam melakukan akitivitas kerjanya terpapar dengan kondisi kerja yang tidak ergonomis. Hal tersebut tidak terlepas dari faktor-faktor yang mengandung risiko bahaya yang dapat mengakibatkan terjadinya masalah berupa keluhan muskuloskeletal dan kelelahan. Tujuan penelitian ini adalah untuk mengetahui keluhan muskuloskeletal dan kelelahan yang dirasakan pekerja saat sebelum dan setelah bekerja. Penelitian ini menggunakan desain penelitian evaluatif dengan sampel sebanyak 11 orang. Data diperoleh dengan wawancara serta menggunakan kuesioner Nordic Body Map untuk mengukur keluhan muskuloskeletal sebelum dan setelah bekerja dan kuesioner 30 Items of Rating Scale untuk mengukur kelelahan sebelum dan setelah bekerja. Data sebelum dan setelah bekerja dari variabel dianalisis stastistik dengan SPSS version 26,0. Hasil analisis data menunjukkan terjadi peningkatan keluhan muskuloskeletal sebelum dan setelah bekerja secara bermakna ( $p=0,00 ; \mathrm{CI}=35,94-41,70)$ sebesar 122,66\%, dan terjadi peningkatan kelelahan sebelum dan setelah bekerja secara bermakna $(p=0,00 ; C I=45,34-49,39)$ sebesar 132,22\%. Kondisi kerja pada UD. Batu Bukit memerlukan tindakan perbaikan untuk meningkatkan kesehatan kerja dengan mempertimbangkan kemampuan industri kecil.
\end{abstract}

Kata Kunci: industri kecil, kelelahan, keluhan muskuloskeletal, kesehatan kerja

\section{Pendahuluan}

Batu alam untuk saat ini banyak diminati oleh masyarakat, baik batu ukir maupun batu tempel yang merupakan hasil kerajinan batu paras dengan hasil produksi seperti, relief untuk dinding atau pagar rumah, patung, ornamen pilar, loster untuk lubang angin-angin rumah, cawan atau pot bunga. Bali, salah satu provinsi di Indonesia, memiliki banyak industri rumah tangga untuk pengolahan, penjualan serta pemasangan batu tempel, salah satunya ialah UD. Batu Bukit. Dalam melakukan akitivitas kerja para pekerja akan terpapar dengan kondisi-kondisi yang tidak ergonomis, seperti melakukan gerakan berulang, menggenggam dengan kekuatan, melakukan postur janggal seperti membungkuk atau menekuk bagian tubuh dan jongkok. Selain itu para pekerja tidak memiliki standar operasional baku yang ditetapkan terkait waktu mulai kerja, waktu istirahat, waktu selesai kerja, waktu lembur, dan waktu libur kerja. Sebagai tambahan, sistem kerja merupakan sistem borongan sehingga keseringan pekerja memaksakan diri untuk bekerja tanpa memperhatikan kondisi fisiologis dan psikologisnya. Hal tersebut dalam proses melakukan aktivitas kerjanya para pekerja tidak terlepas dari faktorfaktor yang mengandung risiko bahaya yang dapat mengakibatkan terjadinya masalah akibat kerja berupa keluhan muskuloskeletal dan kelelahan (Kroemer \& Grandjean, 2009). 
Keluhan muskuloskeletal atau musculoskeletal disorders (MSDs) yang terkadang juga disebut dengan cummulative trauma disorders (CTDs) merupakan gangguan yang terjadi pada otot, saraf, tendon, ligamen, sendi, kartilago, maupun diskus intervertebralis. Gangguan yang terjadi diakibatkan oleh adanya kerusakan yang berupa ketegangan otot, inflamasi, degenerasi, maupun fraktur pada tulang yang disertai dengan rasa nyeri sehingga mengurangi kemampuan gerak (Batara et al., 2021). Keluhan muskuloskeletal terjadi apabila adanya kelelahan dan keletihan terusmenerus yang disebabkan oleh frekuensi atau periode waktu yang lama dari usaha otot dalam menerima beban statis. Selain itu, keluhan muskuloskeletal dapat muncul oleh kerusakan tiba-tiba yang disebabkan adanya aktivitas berat atau pergerakan yang tak terduga (Jalajuwita \& Paskarini, 2015). Keluhan muskuloskeletal yang dirasakan mulai dari keluhan ringan sampai keluhan berat, baik yang bersifat sementara (reversible) maupun menetap (persistent). Keluhan yang bersifat sementara akan segera hilang apabila pembebanan dihentikan, sedangkan pada keluhan yang menetap, rasa sakit pada otot akan terus berlanjut walaupun pembebanan kerja telah dihentikan. Keluhan ringan biasanya akan menghilang setelah istirahat dan tidak mempengaruhi performa kerja, namun apabila keluhan muskuloskeletal sampai ke tahap yang berat nyeri akan tetap ada walaupun setelah istirahat dan akan berpengaruh terhadap pekerjaan (Tarwaka, 2010).

Kelelahan merupakan keadaan fisik dan mental yang berbeda yang berakibat menurunnya ketahanan dan efisiensi dalam bekerja (Anastasia et al., 2021). Lelah yang disebabkan oleh kerja ialah bagian dari kelelahan yang sering terjadi disertai dengan berkurangnya semangat serta niat pekerja melaksanakan tugasnya dan bisa mengurangi produktivitas kerja yang diakibatkan oleh intensitas atau tekanan yang tidak sesuai dengan kapasitas pekerjanya (Supit et al., 2021). World Health Organization (WHO) mengatakan bahwa dalam model kesehatan yang dibuat hingga tahun 2020, diperkirakan gangguan psikologis berupa kelelahan berat dan berujung depresi akan menjadi penyakit pembunuh nomor dua setelah penyakit jantung (Munandar et al., 2017). Data International Labor Organization (ILO) menunjukkan bahwa hampir setiap tahun sebanyak dua juta pekerja meninggal akibat kecelakaan kerja karena kelelahan (Karbito \& Oksandi, 2020). Penelitian yang dilakukan oleh Kementerian Tenaga Kerja Jepang terhadap 12.000 perusahaan yang melibatkan sekitar 16.000 pekerja yang dipilih secara acak menunjukkan bahwa $65 \%$ pekerja mengeluhkan kelelahan fisik akibat pekerjaan rutin, $28 \%$ mengeluh kelelahan mental, dan sekitar 7\% pekerja mengeluhkan stres yang parah (Munandar et al., 2017). Departemen Tenaga Kerja pada tahun 2014 menjelaskan bahwa data mengenai kecelakaan kerja di Indonesia setiap hari rata-rata terjadi 414 kecelakaan kerja, dan
27,8\% disebabkan kelelahan yang cukup tinggi (Mualim \& Yusmidiarti, 2020).

Keluhan muskuloskeletal dan kelelahan merupakan faktor yang dapat menyebabkan turunnya produktivitas kerja, hilangnya jam kerja, tingginya biaya pengobatan dan material, serta rendahnya kualitas kerja. Salah satu usaha yang memiliki resiko terhadap kejadian keluhan muskuloskeletal dan kelelahan yang cukup tinggi ialah usaha sektor informal, khususnya industri rumah tangga UD. Batu Bukit. Tujuan dari penelitian ini untuk mengetahui keluhan muskuloskeletal dan kelelahan yang dirasakan pekerja saat sebelum dan setelah bekerja di UD. Batu Bukit, Desa Kutuh, Kecamatan Kuta Sleatan, Kabupaten Badung, Bali.

\section{Metode}

Penelitian ini menggunakan desain penelitian evaluatif. Sampel pada penelitian ini ialah keseluruhan pekerja yang bekerja di UD. Batu Bukit berjumlah sebanyak 11 orang. Sumber data yang didapatkan merupakan data primer yang diperoleh dengan wawancara serta menggunakan kuesioner Nordic Body Map untuk mengukur keluhan muskuloskeletal yang dirasakan pekerja saat sebelum dan setelah bekerja dan kuesioner 30 Items of Rating Scale untuk mengukur kelelahan yang dirasakan pekerja saat sebelum dan setelah bekerja. Data yang telah diperoleh selanjutnya diolah dan dianalisis dengan bantuan komputer program Statistical Package for The Social Science (SPSS) version 26,0. Variabel keluhan muskuloskeletal dan kelelahan baik sebelum bekerja (pre) maupun setelah bekerja (post) diuji untuk mengetahui sifat distribusi data menggunakan ShapiroWilk Test dengan tingkat kemaknaan $\alpha=0,05$. Kemudian data sebelum bekerja dan setelah bekerja setiap variabel akan diuji menggunakan Paired-Samples T Test apabila data memiliki distribusi normal sedangkan jika terdapat data memiliki distribusi tidak normal diuji menggunakan Wilcoxon Signed Rank Test dengan tingkat kemaknaan $\alpha$ $=0,05$. Penelitian ini dilakukan di lingkungan kerja pengolahan dan penjualan batu tempel UD. Batu Bukit Provinsi Bali. 


\section{Hasil}

Tabel 1. Karakteristik Individu dan Pekerjaan

\begin{tabular}{|c|c|c|c|}
\hline Variabel & $\begin{array}{c}\mathrm{n} \\
(\%)\end{array}$ & Rerata \pm SB & Rentang \\
\hline \multicolumn{4}{|l|}{ Jenis Kelamin } \\
\hline \multirow[t]{2}{*}{ Laki-laki } & 11 & - & - \\
\hline & (100) & - & - \\
\hline \multirow[t]{2}{*}{ Perempuan } & 0 & - & - \\
\hline & (0) & - & - \\
\hline $\begin{array}{l}\text { Usia } \\
\text { (Tahun) }\end{array}$ & - & $43,91 \pm 1,76$ & $42-48$ \\
\hline $\begin{array}{l}\text { Durasi Kerja } \\
\text { (Jam) }\end{array}$ & - & $8,91 \pm 0,94$ & $7-10$ \\
\hline $\begin{array}{l}\text { Masa Kerja } \\
\text { (Tahun) }\end{array}$ & - & $18,36 \pm 3,23$ & $14-24$ \\
\hline
\end{tabular}

Tabel 1 di atas menunjukkan bahwa keseluruhan pekerja di UD. Batu Bukit memiliki usia yang masih tergolong usia produktif, durasi kerja dalam sehari yang tidak ideal karena melebihi 7 jam perhari untuk 6 hari kerja, dan pekerja pada UD. Batu Bukit dilihat dari masa kerja yang dimiliki tergolong sudah handal serta berpengalaman dalam melakukan pekerjaannya.

Tabel 2. Keluhan Muskuloskeletal Sebelum Bekerja dan Setelah Bekerja

\begin{tabular}{lccc}
\hline & Rerata \pm SB & $95 \%$ CI & $p$ \\
\hline Pre & $31,64 \pm 1,50$ & $35,94-41,70$ & 0,00 \\
Post & $70,45 \pm 4,66$ & & \\
\hline
\end{tabular}

Tabel 2 menunjukkan bahwa terjadi peningkatan keluhan muskuloskeletal secara bermakna setelah pekerja menjalani proses kerja dengan persentase peningkatan keluhan muskuloskeletal sebesar 122,66\%, yaitu dari keluhan muskuloskeletal derajat rendah menjadi keluhan muskuloskeletal derajat tinggi. Keluhan paling berat dirasakan pekerja setelah menjalani proses kerja pada bagian tangan kanan, pergelangan tangan kanan, pinggang, leher bagian atas, lutut kanan.

Tabel 3. Kelelahan Sebelum Bekerja dan Setelah Bekerja

\begin{tabular}{lccc}
\hline & Rerata \pm SB & $95 \%$ CI & $p$ \\
\hline Pre & $35,82 \pm 2,64$ & \multirow{2}{*}{$45,34-49,39$} & 0,00 \\
Post & $83,18 \pm 4,62$ & & \\
\hline
\end{tabular}

Tabel 3 di atas bahwa terjadi pengingkatan kelelahan secara bermakna setelah pekerja menjalani proses kerja dengan persentase peningkatan kelelahan sebesar $132,22 \%$, yaitu dari kelelahan derajat rendah menjadi kelelahan derajat tinggi. Dari ketiga kelelahan, yaitu pelemahan kegiatan, pelemahan motivasi, dan kelelahan fisik yang paling berat dirasakan pekerja setelah menjalani proses kerja ialah kelelahan fisik.

\section{Pembahasan}

Menurut analisis menggunakan Nordic Body Map keluhan muskuloskeletal pada pekerja setelah menjalani proses kerja berada pada derajat tinggi hal ini merupakan indikasi diperlukannya tindakan perbaikan kondisi kerja untuk meningkatkan kesehatan kerja di UD. Batu Bukit (Dhari et al., 2017). Keluhan paling berat yang paling utama terjadi pada pekerja berada di bagian tangan kanan dikarenakan dalam melakukan proses kerja pekerja dominan menggunakan tangan kanan untuk melakukan gerakan berulang dan secara bersamaan melakukan tugas menggenggam dengan kekuatan. Kondisi demikian merupakan kondisi yang dapat berkembang ke arah yang lebih buruk yaitu timbulnya masalah kesehatan yaitu Carpal Tunnel Syndrome (CTS) (Ghaisani et al., 2021; Kurniawan et al., 2008; Wardana et al., 2018). Dalam penelitian Sekarsari et al. (2017) hampir serupa dengan pernyataan di atas bahwa ditemukan lebih banyak pekerja pemecah batu mengalami positif CTS dibandingkan yang negatif CTS. Beberapa faktor yang berperan dalam menyebabkan kejadian CTS pada kasus ini ialah usia pekerja yang sudah mendekati usia lanjut. Kroemer dan Gradjean (2009) menyebutkan bahwa keluhan muskuloskeletal akan mulai dirasakan pada usia 30 tahun dan akan terus meningkat seiring bertambahnya usia yang dikarenakan adanya degenerasi jaringan, yaitu sebagian jaringan akan diganti dengan jaringan parut dan berkurangnya kandungan cairan sehingga elastisitas jaringan berkurang yang berisiko tinggi terjadinya cedera pada jaringan muskuloskeletal.

Faktor lain yang menjadi perhatian peneliti ialah durasi kerja yang begitu panjang tanpa adanya penyesuaian waktu istirahat dan kebutuhan nutrisi akan berdampak terhadap terjadinya keluhan muskuloskeletal. Alasan durasi kerja yang tidak dikelola dengan bijak dapat membuat pekerja melakukan aktivitas kerja secara terusmenerus sehingga jaringan yang terlibat akan melampaui ambang batas terhadap tekanan dan gesekan dalam jaringan sehingga menimbulkan kerentanan terhadap cedera jaringan (Hedge, 2017). Adapun faktor lain yang juga menjadi perhatian dalam keterlibatan faktor timbulnya keluhan muskuloskeletal pada pekerja ialah masa kerja. Selain masa kerja menjadi faktor positif terhadap peningkatan kemampuan dan produktivitas kerja seseorang (Saputra et al., 2020) masa kerja juga memiliki dampak negatif terhadap pekerja yaitu timbulnya keluhan muskuloskeletal.

Keluhan muskuloskeletal berhubungan dengan masa kerja apabila dalam menjalani pekerjaan pekerja terpapar dengan kondisi kerja yang tidak ergonomis seperti sikap kerja yang janggal, beban kerja yang tinggi, tidak tepatnya waktu istirahat dengan sifat pekerjaan, 
penggunaan alat kerja yang tidak sesuai dengan antropometri pekerja, ketersediaan nutrisi yang buruk, serta kondisi lingkungan yang ekstrim. Dengan demikian pekerja yang memiliki masa kerja panjang akan terpapar secara rutin dalam waktu yang panjang hingga tahunan sehingga akan terjadi akumulasi keluhan muskuloskeletal (Dul \& Weerdmeester, 2008; Hedge, 2017; Kroemer \& Grandjean, 2009). Keluhan muskuloskeletal terkait pekerjaan yang dibiarkan terjadi pada pekerja akan berdampak buruk terhadap produktivitas kerja, kualitas (Saputra et al., 2020), dan menimbulkan biaya pengeluaran bagi perusahaan maupun pekerja itu sendiri (Bernardes et al., 2021).

Selain permasalahan di atas pekerja di UD. Batu Bukit dari analisis menggunakan 30 Items of Rating Scale kelelahan pada pekerja setelah menjalani proses kerja berada pada derajat tinggi hal ini merupakan indikasi bahwa diperlukan tindakan perbaikan segera (Dhari et al., 2017). Skor kelelahan yang tinggi saat setelah bekerja merupakan kondisi telah terjadinya akumulasi kelelahan akibat menjalani proses kerja yang tidak ergonomis. Hasil pengamatan di lapangan menunjukkan kondisi tidak ergonomis dalam menjalankan proses kerja yang paling menonjol yaitu adanya kebiasaan pekerja untuk memaksakan diri bekerja secara terus-menerus tanpa melakukan istirahat yang tepat. Hal ini dapat membuat tubuh pekerja tidak sempat melakukan pemulihan dan menimbulkan akumulasi kelelahan (Damantalm et al., 2018; Kroemer \& Grandjean, 2009).

Karakteristik individu pekerja, usia memiliki peranan terhadap peningkatan kelelahan kerja karena semakin tua seorang pekerja maka fungsi faal tubuh berubah yang berpengaruh terhadap ketahanan dan kapasitas kerja seseorang (Kusgiyanto et al., 2017). Selanjutnya durasi kerja yang dijalani para pekerja di UD. Batu Bukit memiliki durasi kerja yang panjang dan telah melebihi ketentuan yang telah ditetapkan yang seharusnya dalam 6 hari kerja selama seminggu yaitu tidak melebihi 7 jam perhari (Peraturan Menteri Ketenagakerjaan Republik Indonesia Tentang Keselamatan Dan Kesehatan Kerja Lingkungan Kerja, 2018). Durasi kerja yang panjang tersebut akan berpengaruh terhadap terganggunya siklus sirkadian tubuh yang seharusnya tubuh melakukan istirahat pada waktu tertentu, tetapi tetap dipaksakan untuk bekerja sehingga produksi asam laktat dalam tubuh akan meningkat dan menimbulkan kelelahan. Selain itu juga durasi kerja yang panjang akan membuat beban jantung meningkat hal ini berbanding lurus dengan peningkatan beban kerja, dengan adanya peningkatan beban kerja tanpa melakukan istirahat yang cukup maka kelelahan akan semakin bertambah dan terjadi akumulasi kelelahan (Syaputra \& Winda, 2019).

Faktor lain yang dapat dijelaskan peneliti ialah masa kerja. Semakin lama masa kerja seseorang maka semakin tinggi tingkat kelelahan yang dirasakan karena adanya rasa jenuh yang berhubungan pada kelelahan (Ningsih \& Nilamsari, 2018).

Pada penelitian ini, selain menyampaikan permasalahan kesehatan kerja yang dialami pekerja peneliti juga berusaha untuk menawarkan solusi atas permasalahan yang ada dengan mempertimbangkan kemampuan industri kecil. Solusi yang dapat ditawarkan yaitu dengan pengaturan istirahat pendek, pemberian buah pisang sebagai asupan nutrisi tambahan pekerja untuk menggantikan energi yang sudah dikeluarkan oleh bekerja (Damantalm et al., 2018). Hal penting yang perlu diperhatikan juga untuk melakukan peregangan atau latihan di sela waktu kerja yang dipercaya dapat memperlancar aliran darah melalui vasodilasi pembuluh darah, sehingga beban jantung atau beban kerja berkurang, serta mencegah terjadinya cedera pada jaringan tubuh yang terlibat untuk melakukan aktivitas kerja (Dhari et al., 2017).

Terlepas dari kegiatan penelitian yang dilakukan, ditemukan beberapa keterbatasan dalam penelitian ini. Dalam penelitian ini, peneliti tidak melakukan analisis terhadap faktor-faktor yang berkontribusi untuk terjadinya peningkatan keluhan muskuloskeletal dan kelelahan yang dirasakan pekerja setelah bekerja. Selain itu, beberapa aspek lingkungan seperti suhu, kelembaban, pencahayaan, dan kebisingan tidak diamati dalam penelitian ini.

\section{Kesimpulan}

Pada penelitian ini menghasilkan kesimpulan bahwa keluhan muskuloskeletal meningkat sebesar 122,66\% dari derajat rendah menjadi derajat tinggi dan kelelahan meningkat sebesar $132,22 \%$ dari derajat rendah menjadi derajat tinggi setelah menjalani proses kerja yang tidak ergonomis atau tanpa mempertimbangkan kapasitas pekerjanya. Saran untuk penelitian selanjutnya diharapkan untuk menganalisis faktor-faktor apa saja yang berpengaruh terhadap peningkatan keluhan muskoloskeletal dan kelelahan setelah bekerja pada pekerja di UD. Batu Bukit atau di industri lainnya.

\section{Acknowledgement}

Terima kasih kepada pemilik usaha dan para pekerja UD. Batu Bukit yang telah mengijinkan serta mendukung terlaksananya kegiatan penelitian ini.

\section{Referensi}

Anastasia, N., Kawatu, P. A. T., \& Rumayar, A. A. (2021). Perbedaan tingkat kelelahan kerja berdasarkan shift kerja di minimarket 24 jam kota tomohon. Jurnal KESMAS, 10(2), 147-151. Diakses: $\quad 22 \quad$ Mei 2021 
https://ejournal.unsrat.ac.id/index.php/kesmas/arti cle/view/32291/30638

Batara, G. O., Doda, D. V. D., \& Wungouw, H. I. S. (2021). Keluhan muskuloskeletal akibat penggunaan gawai pada mahasiswa fakultas kedokteran universitas sam ratulangi selama pandemi covid-19. Jurnal Biomedik, 13(2), 152 160. Diakses: $22 \quad$ Mei 2021 https://doi.org/10.35790/jbm.13.2.2021.31767

Bernardes, J. M., Ruiz-Frutos, C., Moro, A. R. P., \& Dias, A. (2021). A low-cost and efficient participatory ergonomic intervention to reduce the burden of work-related musculoskeletal disorders in an industrially developing country: an experience report. International Journal of Occupational Safety and Ergonomics, 27(2), 452459. Diakses: 28 Juni 2021 https://doi.org/10.1080/10803548.2019.1577045

Damantalm, Y., Tirtayasa, K., Adiatmika, I. P. G., Manuaba, I. B. A., Sutjana, I. D. P., \& Sudiajeng, L. (2018). Pemberian buah pisang, istirahat pendek dan peregangan menurunkan keluhan muskuloskeletal, kelelahan dan meningkatkan produktivitas pemanen pengguna alat egrek perkebunan kelapa sawit pt. ssd kalimantan timur. Jurnal Ergonomi Indonesia, 4(1), 47-56. Diakses: $22 \quad$ Mei 2021 https://doi.org/10.24843/JEI.2018.v04.i01.p04

Dhari, I. F. W., Muliarta, I. M., \& Adiputra, L. M. I. S. H. (2017). Pemberian pilates exercise dan modifikasi kondisi kerja menurunkan keluhan subjektif dan meningkatkan produktivitas kerja pada pembatik cap di industri batik. Jurnal Ergonomi Indonesia, 3(1), 19-28. Diakses: 28 Juni 2021

https://doi.org/10.24843/JEI.2017.v03.i01.p03

Dul, J., \& Weerdmeester, B. (2008). Ergonomics for beginners a quick reference guide (Third Edit). CRC Press; Taylor \& Francis Group.

Ghaisani, D. A., Jayanti, S., \& Ekawati, E. (2021). Faktor risiko kejadian carpal tunnel syndrome (cts) pada pekerjaan pengguna komputer: literature review. Jurnal Kesehatan Masyarakat, 9(1), 104-111. Diakses: $22 \quad$ Mei 2021https://ejournal3.undip.ac.id/index.php/jkm/a rticle/view/28607/24988

Hedge, A. (2017). Ergonomic workplace design for health, wellness, and productivity/editor, Alan Hedge. CRC Press; Taylor \& Francis Group.

Jalajuwita, R. N., \& Paskarini, I. (2015). Hubungan posisi kerja dengan keluhan muskuloskeletal pada unit pengelasan $\mathrm{pt} \mathrm{x}$ bekasi. The Indonesian Journal of Occupational Safety and Health, 4(1), 33-42. Diakses: 22 Mei 2021 https://doi.org/10.20473/ijosh.v4i1.2015.33-42

Karbito, A., \& Oksandi, H. (2020). Faktor-faktor yang berhubungan dengan kelelahan kerja pada perawat di rsud dr. h. bob bazar kalianda kabupaten lampung selatan. Jurnal Ilmu Kesehatan Indonesia, 1(1), 1-7. Diakses: 22 Mei 2021 http://jurnal.umitra.ac.id/index.php/JIKSI/article/v iew/330

Kroemer, K. H. E., \& Grandjean, E. (2009). Fitting the task to the human a textbook of occupational ergonomics (Fifth Edit). UK Taylor \& Francis Ltd.

Kurniawan, B., Jayanti, S., \& Setyaningsih, Y. (2008). Faktor risiko kejadian carpal tunnel syndrome (cts) pada wanita pemetik melati di desa karangcengis, purbalingga. Jurnal Promosi Kesehatan Indonesia, 3(1), 31-37. Diakses: 22 Mei 2021 https://doi.org/10.14710/jpki.3.1.31-37

Kusgiyanto, W., Suroto, \& Ekawati. (2017). Analisis hubungan beban kerja fisik, masa kerja, usia, dan jenis kelamin terhadap tingkat kelelahan kerja pada pekerja bagian pembuatan kulit lumpia di kelurahan kranggan kecamatan semarang tengah. Jurnal Kesehatan Masyarakat, 5(5), 413-423. Diakses: $\quad 22 \quad$ Mei 2021 https://ejournal3.undip.ac.id/index.php/jkm/article /view/18963

Peraturan menteri ketenagakerjaan republik indonesia tentang keselamatan dan kesehatan kerja lingkungan kerja, Pub. L. No. 5 (2018).

Mualim, M., \& Yusmidiarti, Y. (2020). Hubungan ergonomi dan psikososial dengan kelelahan kerja pada tenaga kerja perusahaan dagang sinar harapan teknik. Journal of Health Science, 11(2). Diakses: 22 Mei 2021 https://doi.org/10.51712/mitraraflesia.v11i2.19

Munandar, S., Permatasari, A., \& Rezal, F. (2017). Faktor yang berhubungan dengan kelelahan kerja pada karyawan di matahari departement store cabang lippo plaza kendari tahun 2016. Jurnal Ilmiah Mahasiswa Kesehatan Masyarakat, 2(5), 111. Diakses: 22 Mei 2021 https://doi.org/10.37887/jimkesmas.v2i5.2009

Ningsih, S. N. P., \& Nilamsari, N. (2018). Faktor yang berhubungan dengan kelelahan pada pekerja dipo lokomotif pt. Kereta api indonesia (persero). Journal of Industrial Hygiene and Occupational 
Health, 3(1), 69-82. Diakses: 28 Juni 2021 https://doi.org/10.21111/jihoh.v3i1.2439

Saputra, I. K. D. A., Purnawati, S., Swamardika, I. B. A., Adiputra, L. M. I. S. H., Priambadi, I. G. N., \& Dinata, I. M. K. (2020). Kursi lantai dan penataan layout meningkatkan work engagement dan produktivitas pekerja pembuatan atap alang-alang. Jurnal Ergonomi Indonesia, 6(1), 1-8. Diakses: 28 Juni 2021

https://doi.org/10.24843/JEI.2020.v06.i01.p01

Sekarsari, D., Pratiwi, A. D., \& Farzan, A. (2017). Hubungan lama kerja, gerakan repetitif dan postur janggal pada tangan dengan Keluhan carpal tunnel syndrome (cts) pada pekerja pemecah batu di kecamatan Moramo utara kabupaten konawe selatan tahun 2016. Jurnal Ilmiah Mahasiswa Kesehatan Masyarakat, 2(6), 1-9. Diakses: 22 Mei 2021

https://media.neliti.com/media/publications/1867 28-ID-hubungan-lama-kerja-gerakan-repetitifda.pdf

Supit, M. I. A. L., Kawatu, P. A. T., \& Kalesaran, A. F. C. (2021). Hubungan antara stres kerja dengan kelelahan kerja pada petugas llaj dinas perhubungan kota manado. Jurnal KESMAS, 10(3), 95-104. Diakses: 22 Mei 2021 https://ejournal.unsrat.ac.id/index.php/kesmas/arti cle/view/33648

Syaputra, B., \& Winda, P. L. (2019). Pengaruh waktu kerja terhadap kelelahan pada pekerja konstruksi proyek x di jakarta timur. Binawan Student Journal, 1(2), 103-107. Diakses: 28 Juni 2021 http://journal.binawan.ac.id/bsj/article/view/62/63

Tarwaka. (2010). Ergonomi industri: dasar-dasar pengetahuan ergonomi dan aplikasi di tempat kerja. Haarapan Press.

Wardana, E. R., Wijayanti, S., \& Ekawati, E. (2018). Faktor-faktor yang berhubungan dengan kejadian carpal tunnel syndrome (cts) pada pekerja unit assembling pt x kota semarang tahun 2018. Jurnal Kesehatan Masyarakat, 6(5), 502-509. Diakses: $22 \quad$ Mei 2021 https://ejournal3.undip.ac.id/index.php/jkm/article /view/22088 